Short Communication

\title{
Pitting Resistance of the Modified 13Cr Martensitic Stainless Steel in Chloride Solution
}

\author{
Moch. Syaiful Anwar*, Toni Bambang Romijarso, Efendi Mabruri \\ Research Center for Metallurgy and Materials - Indonesian Institute of Sciences (LIPI) \\ Kawasan PUSPIPTEK Building 470 - Tangerang Selatan - Banten - 15314, Indonesia \\ *E-mail: moch026@lipi.go.id
}

doi: $10.20964 / 2018.02 .13$

Received: 19 July 2017 / Accepted: 28 September 2017 / Published: 28 December 2017

In this study, the influence of molybdenum (Mo) and nickel $(\mathrm{Ni})$ on the pitting resistance of the $13 \mathrm{Cr}$ martensitic stainless steels was investigated. X-ray diffraction analysis was performed to analyze the phases formed in the steels. The corrosion studies of $13 \mathrm{Cr}$ steels were performed in the $3.5 \% \mathrm{NaCl}$ solution by cyclic polarization and electrochemical impedance spectroscopy. The corrosion product was studied by SEM and EDX analysis. The results revealed that the addition of Mo and Ni improved the corrosion resistance of $13 \mathrm{Cr}$ martensitic stainless steel in the $3.5 \% \mathrm{NaCl}$ solution.

Keywords: martensitic stainless steel, 13chromium, molybdenum, nickel, corrosion, pitting, chloride, polarization, SEM-EDS

\section{$\underline{\text { FULL TEXT }}$}

(C) 2018 The Authors. Published by ESG (www.electrochemsci.org). This article is an open access article distributed under the terms and conditions of the Creative Commons Attribution license (http://creativecommons.org/licenses/by/4.0/). 